\title{
HUMAN CAPITAL IN THE MODEL OF LOGISTIC KNOWLEDGE MANAGEMENT IN A MICRO-ENTERPRISE
}

\author{
Danuta Janczewska* ๑ http://orcid.org/0000-0003-1013-5665
}

The basic economic resource the means of production -

Is no longer capital, nor natural resources, nor labour. It is and will be knowledge

Peter F. Drucker.

\begin{abstract}
Background. In the last years micro-enterprises from the SME sector have been the subject of interest and discussion due to their significant share in the total number of enterprises and a significant contribution to the production of national income. This is a phenomenon that occurs both in Poland and in the European Union. There is, however, no research in both the micro enterprise sector and phenomena occurring in individual enterprises over the issues of the possibility of raising competitiveness. regarding the possibility of their development and achieving competitive advantages. Few theoretical studies also touch the issues of knowledge management methods in micro-enterprises, the conditions for the implementation of knowledge and the expected economic effects. Due to the increased complexity and dynamism of the organization's environment, better use of human capital and improvement of knowledge management methods is becoming more and more important. The development of human capital can be implemented through specific activities, which include extending the tasks of the employee, enriching work and introducing modern technologies, training and broadly understood education. In order for these activities to be effective, the enterprise should define specific conditions related to the implementation of basic development goals, including the role of human capital. Logistic processes of the enterprise and their improvement in terms of human resources can become such an imperative.
\end{abstract}

Research aims. The aims of the article are (1) to present research on knowledge management and the role of human capital in a micro-enterprise based on the

\footnotetext{
Social Academy of Science in Lodz, Sienkiewicza 9, 99-113 Łódź, Poland. E-mail: djanczewska@spoleczna.pl
} 
methodological concept of process management knowledge and (2) to present a case study and the results of non-participant observation using online management tools as research tools in the presented area.

Methodology. In the process of constructing the methodological concept, that is the studied group of enterprises, extensive literature of the subject in the field of management sciences was used. Non participant observation was carried out with the participation of 40 master degree students in management, whose task was to prepare a given individual research project. In this way, we obtained data verifying the suitability of the presented research method.

Key findings. The presented research method allows to some extent to identify problems occurring in micro-enterprises in the field of studying the share of human capital in the logistic knowledge management model and is a step towards further research.

Keywords: human capital, logistics, knowledge management.

JEL Codes: M12

\section{INTRODUCTION}

One of the important phenomena in the modern world is the reorientation of the modern economy consisting in the transition from a material-intensive economy to a one based on information and knowledge. Different formulation of the rules of competing economies with their material resources in favor of intangible resources, such as human capital, knowledge, new technologies is characteristic for this reorientation. Achieving a high level of competitiveness is now the goal of enterprises and economies appreciating the key role of knowledge and innovation. In the literature on the subject, one can find numerous examples of publications presenting the management of organizational knowledge and non-material resources of the organization (Von Krogh et al., 2001). Defining knowledge in the 21st century requires the collection of data and information in order to use them or to process them in a different context than it has been so far due to the dynamic development of information technologies accelerating the diffusion of knowledge. Successes can be achieved by organizations that have the skills to create, use and develop knowledge-based resources (Hill et al., 2002; Morrison $\&$ Bergin-Seers, 2002; Sveiby, 1997; Teece, 2000). One of the trends in the research of knowledge as a resource is the search for knowledge management models and building the company's intellectual capital. The issue of knowledge and intellectual capital of micro-enterprises is 
rarely addressed in the literature on the subject (Janczewska, 2014a, p. 194). There are no studies of the micro-enterprise sector regarding the possibilities of their development and achieving competitive advantages. Research by R. Karaszewski and M. Klemke-Pitek showed that Polish entrepreneurs are not aware of the importance of acquiring, developing, storing knowledge resources and do not have effective tools for efficient management of this resource (Karaszewski \& Klemke-Pitek, 2012, p. $55)$. They pointed to the need to conduct research on knowledge and innovation management in enterprises with the support of the European Union and the use of EU funds. The following issues should be addressed in the scope of these studies:

- searching for tools to measure the company's knowledge,

- motivating employees to build the company's knowledge and transform it into innovative solutions,

- contribution of employees to building knowledge and innovativeness of the enterprise as part of the implementation of EU projects.

The article aims to present a theoretical approach to the issue of human capital in a micro-enterprise and to identify the function that this resource performs in the model of logistics management in an enterprise. The theoretical part presents contemporary views on human resource management models and knowledge management in micro-enterprises. The following problem issues were formulated, which were then verified in the research process:

P1: In a micro-enterprise one can indicate factors stimulating knowledge management, including logistic knowledge, acquiring this knowledge and its diffusion.

P2: Human capital is an important element in the process of logistics knowledge management.

The empirical part is a pilot project examining the manifestations of the impact of human capital on knowledge management in logistics processes.

\section{HUMAN CAPITAL IN AN ENTERPRISE}

Human capital is defined as: knowledge, competences, abilities, skills, know-how, culture, values, relationships, motivation, attitudes, intellectual skill and leadership. Sajkiewicz believes that: 
(...) human capital is people permanently connected with the company and its mission, characterized by the ability to cooperate, creativity attitudes and qualifications. They constitute the motor and heart of the company, without which its further development becomes impossible (Sajkiewicz, 1999, p. 79).

Human capital is a component of the company's non-material resources, which is why the further parts of the article give a broader interpretation of issues related to intellectual capital. In order to show the complexity of the subject, the theories and concepts of intellectual capital management have been presented.

The concept of strategic HR management has found a reflection in personal function models and their enterprise structures derived from the USA (Listwan, 2006, p. 48). The most known models include:

- Michigan model-showing the process of strategic human resources management, taking into account the environment, mission, organization structure and human resources management,

- Harvard model - assumes that the pressure of various factors on the company requires a different look at human resources, a more strategic perspective, involvement in the process of managing line supervisors,

- Schuler model - In which it is assumed that the strategy of the organization has the overriding importance of activities in the area of strategic human resource management,

- $\quad$ sieve model - based on competition and rivalry as the main stimulators of employee behavior and efficiency,

- human capital model - is characterized by treating employees as capital, which should be developed through learning,

- knowledge management process model.

In the management of human capital and its creation in the enterprise, four models of the personnel policy of creating the human capital of the organization were taken into account (Schuler, 1992, p. 18):

- model of human capital development,

- model for acquiring human capital,

- model for contracting human capital,

- model of creating alliances in the field of human capital.

The most popular tools used to develop human capital in the enterprise are remote teaching instruments, using computer techniques, the Internet or interactive TV. Currently, groupware systems are used that ensure the flow and sharing of knowledge (Kamińska, 2016, p. 166). 
Human capital management is integrally linked to the appropriate management style. Penc reports that the style of management is a relatively permanent and repeatable way of influencing the subordinates to stimulate and coordinate their team activities aimed at achieving the goals faced by the organization (Penc, 1997, p. 427). The definition indicates the individual character of the management style - which is confirmed by the published research results. Research on the styles of human resources management on the example of Polish hospitals has shown that the autocratic style prevails (Sułkowska \& Sułkowski, 2011, p. 56).

The concept of the intellectual capital of the organization is related to human capital, because the personnel employed in the organization creates its intellectual resources. The concept of intellectual capital is related to the Konrad Report, which was created in 1989 as a result of the work of a group of Swedish scientists gathered within the initiative of Sveiby in 1987 (Szopik-Depczyńska \& Korzeniewicz, 2011, p. 185). Intellectual capital being the sum of various categories of knowledge in an enterprise can also be valued - which requires the use of individual evaluation and assessment methods. These characteristics were pointed out by Edvinsson and Malone (Edvinsson \& Malone, 2001, p. 39) who in the 1990s were studying the intellectual capital of the Swedish company Scandia. They formulated the following descriptions of the characteristics of intellectual capital:

- information on the company's intellectual capital is an additional but equally important supporting information,

- intellectual capital is non-financial capital, being the equivalent of the difference between the market value of the company and the book value,

- intellectual capital is a commitment, which means that it was created as borrowing from interest groups - employees, customers and should be recorded as the company's equity.

Few studies presented in the available literature focus on the issues of management, competitiveness and the issue of intellectual capital management in micro-enterprises. There is, in particular, no definition of the intellectual capital of the organization in the sense of its non-material character and common view on the subject (Czechowska-Świtaj, 2005, p. 46). Issues related to knowledge management in micro-enterprises are not the subject of research, and there are few publications that present fragmentary research or observations. 
M. Kozioł presents the view that one of the most important internal barriers to the development of a small enterprise is the educational barrier (Kozioł, 2013, p. 48). He lists the following factors hindering the development of a SME sector company:

- poor entrepreneurial culture,

- poor knowledge of modern management methods,

- limited access to business information,

- lack of ability to acquire, collect and use information from the environment,

- low use of the Internet and other IT tools,

- gaps in the qualification potential due to low qualifications of the employees,

- high fluctuation of employees, especially specialists,

- low ability and inclination to learn,

- lack of education system in the field of small business and others.

Research on the management of intellectual capital in a micro-enterprise was conducted by A. Sokołowska (Sokołowska, 2005, p. 93), during which small companies (employing up to 50 people) were examined using the survey method and micro enterprises were distinguished. She studied models of intellectual capital management in small organizations in the aspect of using intellectual capital. She pointed to significant barriers to the use and development of intellectual capital in micro-enterprises, in which the owners were interested in raising their own qualifications, education etc. Referring to the results presented by Edvinsson and Malone, it can be concluded that it is difficult to describe and measure intellectual capital in micro-enterprises, there is also asymmetry in shaping its structure and dynamics.

\section{KNOWLEDGE MANAGEMENT IN AN ENTERPRISE}

The 21st century is a period in which knowledge becomes a competitive element of advantage, while the skill of continuous improvement contributes to the development of enterprises. According to Gierszewska, the introduction of new products and services requires the company not only to apply modern technologies and production techniques, but to transform its knowledge resources into innovative solutions 
(Gierszewska, 2011, p. 7). Contemporary understanding of sources of knowledge is modified because the way and place of knowledge creation have been attributed to the institutions of the sphere of science, such as universities, research institutes and centers - and enterprises are starting to acquire this role now. They generate knowledge, using it to improve their own products, production technologies or methods of management and organization of work. New organizational forms are also being created that collect, process and offer information - so-called knowledge houses. Determining the significant position of knowledge resources in a micro-enterprise can be implemented through the following assignments (Bławat, 2003, p. 42):

- $\quad$ know-what (e.g. to apply organizational improvement),

- know-why (e.g. manufacturing costs are rising, the company is not able to keep up with orders),

- know-how (know how to improve work organization or manufacturing technology),

- $\quad$ know-who (know who can make the product best, develop a new product composition),

- $\quad$ know-when (know when it is best to implement new technology or organizational improvement),

- know-which (know which areas of the company's operation should be paid attention to, or where the so-called bottlenecks in production lie),

- $\quad$ know-between (to know what kind of relationships exist between the elements of the system, that is a given company or between a company and its environment),

- $\quad$ know-where (e.g. where to look for subcontractors, sub-suppliers, new knowledge or new clients),

- know-whether (to know whether, for example, a new venture is profitable, whether a new customer will become a loyal customer or whether entering a new market is not too risky for the company),

- $\quad$ know-if (to know on what condition one can start a new project or start cooperation with another company).

In modern economies, and thus in the enterprises as well, there are numerous processes that are generated and stimulated by knowledge and human capital (Sydanmaanlakka, 2002). These processes result in an increase in the impact of knowledge on company management in the following areas: 
- number and variety of knowledge increases exponentially,

- importance of human capital generating and creating new knowledge increases,

- changes in technological knowledge of a radical nature (it is expected that in the next two decades there will be more technological changes than in the entire history to date),

- development of Internet, information and communication technologies,

- $\quad$ progressive globalization as a result of constant changes in the political and economic environment,

- $\quad$ increase in the importance of public-private partnerships under the triple helix model,

- creating new innovation models: open innovations as new models for the implementation of research and development activities,

- increase in the importance of small and medium-sized enterprises as carriers of economic growth,

- $\quad$ radical changes in the social environment, including changes in the existing changes in social values, the emergence of network structures (Malara, 2009, p. 809).

The above changes make it necessary for enterprises to adapt and, therefore, to acquire new knowledge and manage it. The main areas of business activity are extended by the processes of acquiring and processing knowledge and its implementation. Research works known from the literature concern large enterprises in which phenomena related to knowledge management and human capital can be identified and described, defined on the basis of known theoretical models. Well-known knowledge management models based on the experience of large enterprises cannot be applied in micro-enterprises due to different organizational structures and management systems.

\section{KNOWLEDGE MANAGEMENT MODELS IN LITERATURE}

The knowledge management models presented in the literature focus on identifying factors that stimulate knowledge management (Bodrow, 2006 , p. 41). The precursors to research on knowledge management 
include: Nonaka and Takeuchi (1995), Sveiby (1998), Probst et al. (1999) and many others. All authors point to the significant role of human capital in creating knowledge management processes, especially through the involvement of all people in the organization in these processes. Knowledge is not only a collection of data and information, but also: values, emotions and intuitions (Janczewska, 2016b). In addition to knowledge management, enterprises should strive to create it and involve all employees in the process of creating knowledge. Acquiring knowledge in a modern enterprise requires the use of developed IT systems and software enabling the creation of databases, data warehouses and knowledge repositories. An important element of the organization's competences is learning, especially team learning. Among the statements of contemporary researchers of the knowledge management process, the aspect of the impact of organizational culture on the nature and structure of the process is emphasized (Grudzewski \& Hejduk, 2006, p. 13), especially in the context of storing and disseminating knowledge. Peter Senge (2012) is considered to be the propagator of the idea of learning organizations. He presented criteria that combine activities in the company and its resources of knowledge with the transposition of future development and the transformation of knowledge into innovation. Among the many contemporary models of knowledge management, the most well-known are as follows:

- The Japanese model is considered the most innovative and forward-looking approach to knowledge management and is based on two categories of knowledge: tacit knowledge and formal knowledge. It was created by two Japanese scientists: I. Nonaka and H. Takeuchi, who presented a knowledge management model based on the "spiral of knowledge", which is formed by the following processes of knowledge transformation:

- socialization, or exchange of tacit (hidden) knowledge into a tacit (hidden) knowledge,

- externalization, or exchange of tacit (hidden) knowledge into formal (available) knowledge,

- combination, or exchange of formal (available) knowledge into formal (available) knowledge,

- internalization, or exchange of formal (available) knowledge into a tacit (hidden) knowledge. 
- The resource model - combines key business skills with elements of the environment in a given time horizon. It is based on the concepts presented by D. Leonard-Barton known as models of "sources of knowledge", such as:

- key skills that include physical and technical systems, management systems, employee knowledge and skills, standards and values,

- joint problem solving,

- implementation and integration of new tools and technologies,

- experimentation,

- importing knowledge.

Other models based on solutions and practical experience of large consulting companies combine the process approach. D.T. Davenport and L. Prusak from the IBM Consulting Group, G. Probst and S. Raub as well as W.R. Bukowitz and R.L. Wilson contribute greatly to the development of the process model concept (Sopińska \& Wachowiak, 2006, p. 12).

Among the modern forms of activity of micro-enterprises, network-type activities are mentioned, characterized by the possibility of combining the individual way of increasing competitiveness with the direction of cooperation with other enterprises (Janczewska, 2014b, p. 13). In the context of many dimensions of knowledge necessary in the enterprise one can point to the interdisciplinary character of this resource, covering many categories and areas, among which one can indicate such as:

- technology and technique appropriate for a given sector or industry in which the enterprise operates,

- economics to the extent necessary for use in an enterprise,

- organization and management as an ability to optimally plan and implement the company's operations and use appropriate instruments in this area,

- marketing - indispensable for correct reading of signals from the market and making a dialogue with clients and other market participants,

- logistics - as a specific and unique area of application of logistic knowledge to support process management in an enterprise,

- IT and the use of IT technology - to the extent necessary for proper communication within the enterprise and between 
the company and the environment as well as within the scope required for broadly understood business management.

The concept of intelligent organization appeared in the mid-twentieth century. The definition occurs in many literature sources and is based on the organization's learning process. In the system approach named "the fifth discipline" by Peter Senge (2012), thanks to knowledge and appropriate tools, all the components of the organization and its employees are able to skillfully interact, successfully accomplishing goals and tasks. The intelligent organization has a significant share of human capital in the use of knowledge for the development of its own company, which attaches great importance to knowledge, incurs significant financial expenditures on the development of IT infrastructure, software and knowledge management systems (Łobejko, 2009, p. 3). Research conducted in 2010 by Małgorzata Juchniewicz and Barbara Grzybowska focused on the determinants of creating innovation by micro-enterprises, among others as the effect of knowledge management (Juchniewicz \& Grzybowska, 2010), pointing to the low innovativeness of micro-enterprises. The results of the research confirmed earlier conclusions of Żołnierski indicating low use of knowledge and low innovation rates (Żołnierski, 2005, p. 5).

Not all of many known models of knowledge management can be used to interpret the process of managing logistics knowledge in a micro-enterprise (Janczewska, 2014a). The linear model based on a process approach seems the most suitable to condition the functioning of a micro-enterprise. In the linear model shown in Figure 1, the relationship between searching for knowledge and its implementation in a micro-enterprise is shown. This model describes in a simplified way the interactions between individual stages of acquiring and using knowledge (Gierszewska, 2011, p. 88)

Logistics in the company ensures efficient implementation of processes and is the source of their improvement. The management of logistic knowledge is related to the spectrum of the company's market activity and its logistics processes, such as: procurement, production or provision of services, distribution and other supporting processes (Janczewska 2017a, p. 193). The linear model does not comprehensively influence the environment and does not distinguish between different categories of knowledge. However, it is so simplified that it can be used by owners or employees of micro-enterprises who do not have specialist logistic knowledge in the theoretical perspective. 


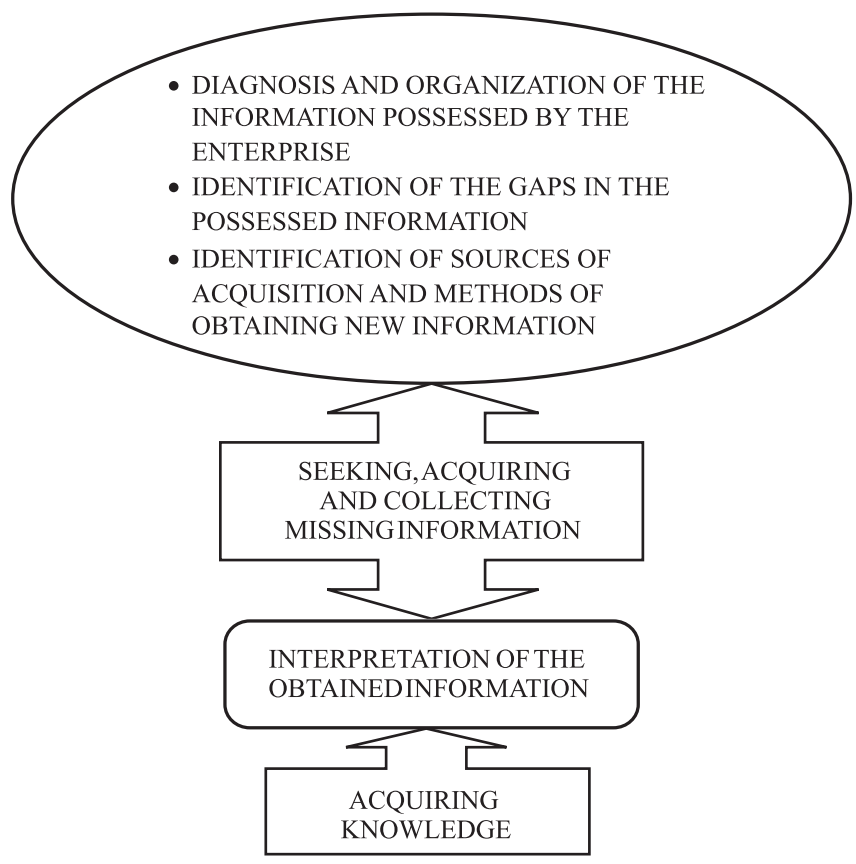

Figure 1. Linear model of knowledge management

Source: author's own elaboration based on: Gierszewska, 2011, pp. 88-90.

Logistics knowledge covers theoretical foundations of logistics management and practical knowledge. The effective functioning of the enterprise's logistics system requires the possession of appropriate knowledge resources in all areas of logistics processes. The role of human capital is significant in knowledge management in the logistics process, mainly due to activities and operations performed by the employees (Janczewska 2017b, p. 198). These include: receiving orders from customers, purchasing necessary supplies and raw materials, product or service implementation, distribution, after-sales service of customers. (Janczewska 2017c, p. 77)

Figure 2 shows the author's model of logistics knowledge management in a micro-enterprise, based on a linear model. The course of the logistics process is presented in the form of three stages: entry - introduction to the process, its implementation and exit from the process. Each stage presents its characteristic elements, such as the description of a given stage, then the knowledge resources necessary to complete the stage, and the third element is defined as the human capital supporting the 
implementation of the stage. In the case of a micro-enterprise with a few employees, a situation may arise in which the same employee will participate in all three stages of the logistics process.

\begin{tabular}{|c|c|c|}
\hline $\begin{array}{l}\text { ENTRY to logistic } \\
\text { process: } \\
\text { - defining interneal } \\
\text { and external conditions } \\
\text { in accordance with } \\
\text { customer's order } \\
\text { - determining values that } \\
\text { are significant for the } \\
\text { customer } \\
\text { - defining resources } \\
\text { necessary to achieve } \\
\text { the goal } \\
\text { Knowledge resources: } \\
\text { Intellectual capital. } \\
\text { Ability to study the } \\
\text { environment. Knowledge } \\
\text { of the trends in the sector } \\
\text { Human capital } \\
\text { employee with logistics } \\
\text { education, knowledge } \\
\text { of logistic processes }\end{array}$ & $\begin{array}{l}\text { REALIZATION } \\
\text { OF THE PROCESS: } \\
\text { creating values significant } \\
\text { for the customer, } \\
\text { implementation and } \\
\text { development of } \\
\text { managerial processes, } \\
\text { making decisions and their } \\
\text { monitoring } \\
\text { Knowledge resources } \\
\text { Performing and technical } \\
\text { skills. } \\
\text { Technical and IT infrastructure } \\
\text { Managerial competences. } \\
\text { Human capital } \\
\text { employee with technical, } \\
\text { specialized knowledge }\end{array}$ & $\begin{array}{l}\text { EXIT from the logistic } \\
\text { process: } \\
\text { - realization of customer's } \\
\text { orders } \\
\text { - obtaining valued planned } \\
\text { for the customer } \\
\text { - implemented innovative } \\
\text { products or organizational } \\
\text { solutions } \\
\text { - development of new } \\
\text { organizational structures } \\
\text { - profit or other tangible effects } \\
\text { Knowledge resources: Ability } \\
\text { to monitor effects and to } \\
\text { define and implement } \\
\text { corrective actions } \\
\text { Human capital: } \\
\text { team of employees realizing } \\
\text { post sales service, } \\
\text { assessing the effectiveness } \\
\text { of logistic process }\end{array}$ \\
\hline
\end{tabular}

Figure 2. Logistics knowledge management model in a micro-enterprise

Source: author's own elaboration based on: Janczewska, 2016a, pp. 164-175.

Based on the author's model, it is possible to determine how knowledge is acquired, collected and processed through the description of individual subsequent elements of the process. It can therefore be used in a micro-enterprise in the absence of preparation for knowledge management or at the stage of its creation. It is required to create additional descriptions and identify structures and logistic resources including logistics processes implemented by the micro-enterprise. In the research, the logistics management model was verified and the role of human capital was defined in it.

\section{DISCUSSION OF AUTHOR'S RESEARCH}

The research was conducted in 2017/2018 among 40 companies from all over Poland. The aim of the research was to identify the manifestations of knowledge management, including the verification of the author's 
logistic management model and to determine the share of human capital in this process. Students of the final years of master's studies in the field of management of the University of Social Sciences in Lodz studying in the e-learning system participated in the study. Surveys were conducted in enterprises within the framework of the project during a course on Knowledge Management in Organizations. The sample was not representative and the conclusions from the study refer only to the surveyed enterprises. Before the examination an information lecture was conducted. An e-learning platform was used to receive surveys. In the surveyed group of enterprises, $20 \%$ were micro-enterprises: In the micro-enterprises studied, companies run by natural persons were prevailing (80\%), the remaining $20 \%$ were family enterprises. The industry structure of the surveyed companies by type of activity was as follows:

- $20 \%$ - commercial activity,

- $\quad 80 \%$ - service activity.

The studied micro-enterprises were mainly active on local markets (60\%), nationwide (30\%) and operations outside the country (10\%). 30\% of the surveyed micro-enterprises pointed to the traditional features of human capital management, including such features as:

- domination of material resources over the knowledge resources,

- lack of close ties to the environment,

- hierarchical organizational structure and lack of communication at the same level of the organizational structure,

- occurrence of minor - mainly organizational - improvements,

- organizational culture focused on loyalty and discipline.

$70 \%$ of respondents indicated the advantage of features characteristic of the company's knowledge, such as: the degree of modernity of products, the level of product quality, responding to customer needs, company competitiveness and qualifications of the managerial staff and the degree of computerization.

Management features occurring in the examined micro-enterprises are presented in table 1.

Logistic processes occurring in micro-enterprises are different from those that are carried out in large organizations, but these differences are not only due to the size of the enterprise and resources. The logistic processes in the micro-enterprise include:

- processes supporting the physical flow of materials and goods, such as supply, storage, production, distribution, transport processes, 
- $\quad$ processes supporting the flow of information, such as communication processes, monitoring of processes, registering process parameters,

- $\quad$ processes supporting logistic customer service, such as interactive use of the Internet, use of IT tools.

Table 1. Management areas in the studied micro-enterprises

\begin{tabular}{|c|c|}
\hline $\begin{array}{c}\text { Selected } \\
\text { management areas }\end{array}$ & $\begin{array}{l}\text { Micro-enterprise } \\
\text { (1-9 employees) }\end{array}$ \\
\hline $\begin{array}{l}\text { Shaping the organi- } \\
\text { zational structure }\end{array}$ & $\begin{array}{l}\text { A simplified or missing structure, horizontal, flattened, } \\
\text { structure, the owner manages employees directly. Combining } \\
\text { ownership and management }\end{array}$ \\
\hline Personnel system & $\begin{array}{l}\text { Self-employment, family business, limited number of employees } \\
\text { performing tasks }\end{array}$ \\
\hline Managerial functions & $\begin{array}{l}\text { The owner is also the manager. A centralized way of manage- } \\
\text { ment }\end{array}$ \\
\hline $\begin{array}{l}\text { Knowledge } \\
\text { management }\end{array}$ & $\begin{array}{l}\text { Practical knowledge based on the owner's experience. No sys- } \\
\text { temic knowledge management }\end{array}$ \\
\hline $\begin{array}{l}\text { Human capital } \\
\text { management }\end{array}$ & $\begin{array}{l}\text { Limited number of employees, often without appropriate skills } \\
\text { and competences. Managing employees directly by the owner. } \\
\text { Command-type management style predominates }\end{array}$ \\
\hline $\begin{array}{l}\text { Setting strategic } \\
\text { goals }\end{array}$ & $\begin{array}{l}\text { The owner sets the company's strategic goals intuitively, rarely } \\
\text { uses the help of specialists. The proximity of the market is deci- } \\
\text { sive. Choosing a niche strategy or lack of strategy - an attitude } \\
\text { towards survival }\end{array}$ \\
\hline $\begin{array}{l}\text { Logistics and } \\
\text { marketing }\end{array}$ & $\begin{array}{l}\text { Lack of precise marketing orientation, sporadic use of market- } \\
\text { ing instruments, logistics processes focused on internal resourc- } \\
\text { es - based on customary customer relations }\end{array}$ \\
\hline Innovations & $\begin{array}{l}\text { A narrow, niche specialization in a field of little interest to large } \\
\text { companies }\end{array}$ \\
\hline Planning system & $\begin{array}{l}\text { Lack of planning on the part of the owner or short-term plan- } \\
\text { ning, related to the company's current activities }\end{array}$ \\
\hline Organizing work & $\begin{array}{l}\text { A low degree of formalization of tasks. No bureaucracy. Or- } \\
\text { ganizing the owner's work concerns products or unit services, } \\
\text { individual or simple construction products }\end{array}$ \\
\hline Decision-making & $\begin{array}{l}\text { Fast decision making by the owner, risk aversion, fear of losing } \\
\text { the market }\end{array}$ \\
\hline Control systems & Personal supervision of the owner over the entire company \\
\hline Change management & $\begin{array}{l}\text { Responding to customer needs, specific and direct relationships } \\
\text { with clients }\end{array}$ \\
\hline
\end{tabular}

Source: author's own elaboration based on: Nogalski et al., 2004, p. 26; Janczewska, 2011, pp. 179-192. 
An example of the result of a micronterprise study based on a survey in micro-enterprise $\mathrm{X}$, operating in the high-tech industry is presented below. The case study was conducted in the form of participant observation (student-interviewer is an employee of the described company). The company operates on the domestic market, in the service industry.

\section{Description of micro-enterprise $\mathrm{X}$}

The company operates in the high-tech area, hence by definition is a knowledge enterprise. The main product is computer software. Moving away from this area of operation would in practice mean an immediate collapse of the company due to lack of ability to compete on the market. As can be seen from the above indicators, the company meets almost all the criteria that determine it as a knowledge company, especially in the area of having an educated workforce. Activities and products of the competition are constantly monitored, but the projects are carried out jointly with the entities whose offer is complementary to the offer of the enterprise $\mathrm{X}$, and is not its competition. The lack of cooperation with the competition does not mean here the lack of contacts with competing companies, but only the lack of closer relationships and implementation of joint projects.

\section{Assessment of intellectual capital}

The most important are the employees who decide about the functioning of the company. The company employs top-class specialists - all of them have higher education, supplemented with additional courses and trainings as well as extensive experience in the industry. The company invites young talented students and graduates of higher education to apprenticeships and internships, periodically also employing some of them and allowing them to gain professional experience. The knowledge, the quality of the products (to create which it is necessary to effectively use the latest technologies) is important. The subscription system enforces the need to maintain long-lasting relationships with customers and high quality of products. 


\section{Sources of knowledge in the studied micro-enterprise}

- Studies - all employees of the enterprise have higher education (one bachelor's, currently supplemented with master's degree, the others - master's or engineering master's). The entire staff completed their studies in the field related to their work (business or technical), which means that the knowledge acquired during the studies is used in everyday practice. The knowledge is also provided by young students and graduates taking apprenticeships or internships, or employed for a limited time as younger specialists.

- Off-site training - producing the software, the enterprise uses many IT tools produced by other companies (e.g. Google or Microsoft). In the case of new solutions that can be used, employees are trained by these companies. They also use - if necessary - other thematic trainings, e.g. related to changes in regulations. An example here may be regular trainings on changes in tax regulations or trainings related with the GDPR legislation. There are also external trainings related to implementations in enterprises operating in specific industries - e.g. in trade in ores, works of art or animal livestock.

- Conferences and sector meetings - several times a year the enterprise participates in conferences or sector meetings, both strictly IT as well as business related. These are often conferences organized by partners - especially Microsoft, but it also participates, for example, in GigaCon conferences. It should be emphasized, however, that this is only an addition to the core business and the company is not overly focused here.

- Professional literature - the employees constantly develop their skills, reading professional literature and industry press. They also quite often write articles, which then appear in the media. Employees of the company have published books as well.

- Internet -it is, apart from professional literature and courses, the basic source of knowledge acquisition in the process of self-education of employees and the exchange of experience. Due to the wide range of available materials and their quick 
update, this should be considered as the most important source in acquiring up-to-date knowledge.

- Discussions with colleagues at work - exchange of experience in the course of direct discussions is a standard in the enterprise X. All employees are passionate in the field, which they devote themselves to professionally, at the same time flat structure and organizational culture facilitate the exchange of knowledge. Hence both solving many current problems during the discussion and brainstorming as well as sharing the latest acquired knowledge take place on an ongoing basis. The fact that someone has acquired unique knowledge ennobles him in the eyes of other employees, hence the willingness to share his knowledge and skills. Sharing knowledge is also favored by a small number of employees - passing knowledge to another person allows for a more flexible distribution of tasks among individual employees.

- Database and information in the company - due to the small size of the enterprise, many processes are deformalized. Nevertheless, much of the knowledge is codified and recorded in the knowledge bases. In the enterprise X, knowledge (apart from that personalized, tacit one, collected in the minds of employees) is coded in the form of documents (notes, project documentation, internal documentation) and stored in knowledge bases, available to employees. There are also collected lists of textbooks, magazines, websites - and physical information carriers (books, CDs, magazines) in the library of the enterprise. Finally, other well-established knowledge resources are collected - such as demo versions of competitors 'products, documentation for these products, notes from the launching events of competitors' products or user opinions about these products, available even on the Internet (including social media). Internal knowledge bases, organized in this way, greatly accelerate the process of adaptation of new employees. The knowledge bases are protected and access to them is provided by certain people in the enterprise.

- Professional experience - subsequent implementations, especially non-typical ones, increase the professional experience of individual employees, thus becoming a source of personalized knowledge that is later passed on to other employees. Thanks 
to coding (notes, project documentation) - these experiences are also a source of explicit knowledge stored in the enterprise's databases.

- Customers - Customers using the enterprise's products submit their comments regarding their functioning, but also their suggestions as to the expected directions of their development. These comments are often the beginning of cooperation that allows to obtain (theoretical and practical) knowledge in new areas. The same applies to new customers - the pre-implementation analysis of the industry in which the client operates and the way in which his company operates usually allows him to acquire valuable domain knowledge. In order to prepare guidelines for the implementation process, analysts must carefully analyze all the nuances associated with the specificity of the industry and a specific enterprise, often becoming experts in this field: they know accounting not worse than many accountants, warehouse management better than most warehouse keepers, efficiently move in tax regulations, and often in non-typical areas, such as issues related to the sale of ores or works of art. A large part of this knowledge is obtained from future clients as part of pre-implementation analyzes.

- Competitors - they become a source of knowledge thanks to the analysis of their actions on the market and their products. The enterprise not only tests the products of the competition, but also their acceptance by the market and users' opinions about them. Thanks to this, it can use good solutions (often improving them) and avoid faulty solutions, learning somehow from other people's mistakes. Of course, to a limited extent, because many solutions are innovative and have no equivalent on the market.

Table 2 presents a description of the elements of the knowledge management process in the examined micro-enterprise. 


\begin{tabular}{|c|c|c|c|c|}
\hline 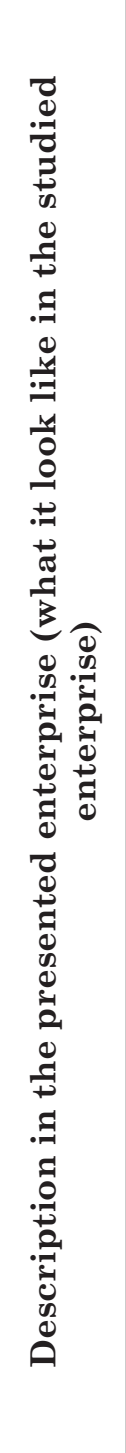 & 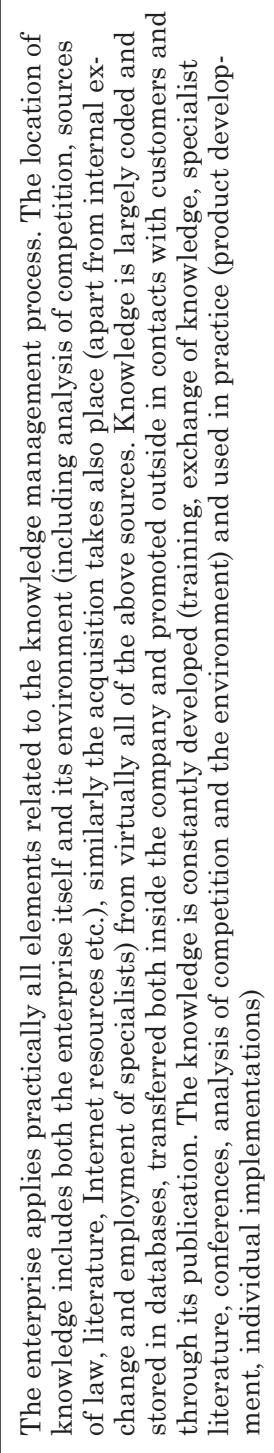 & 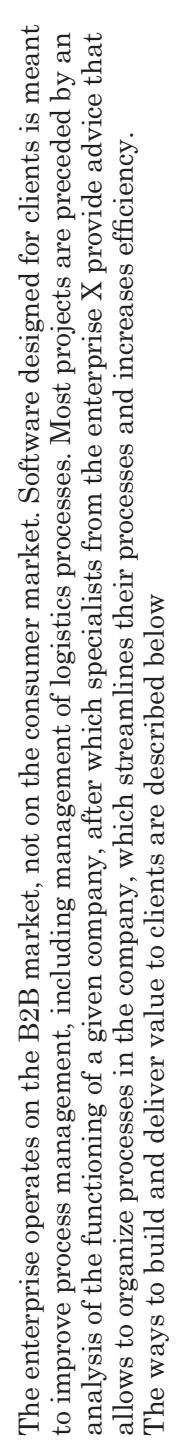 & 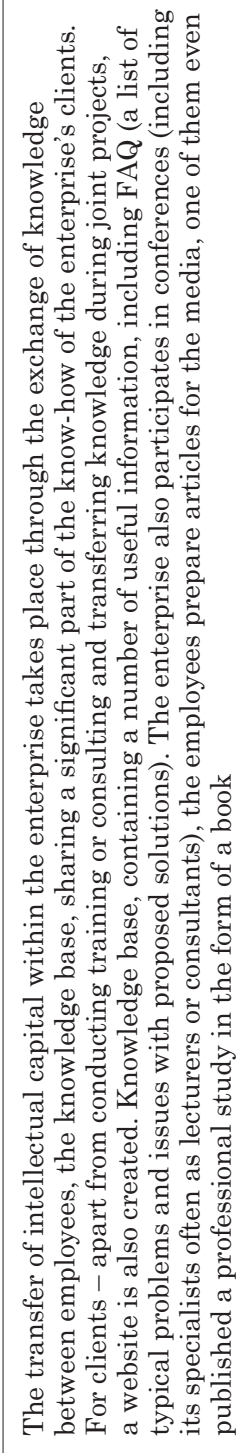 & 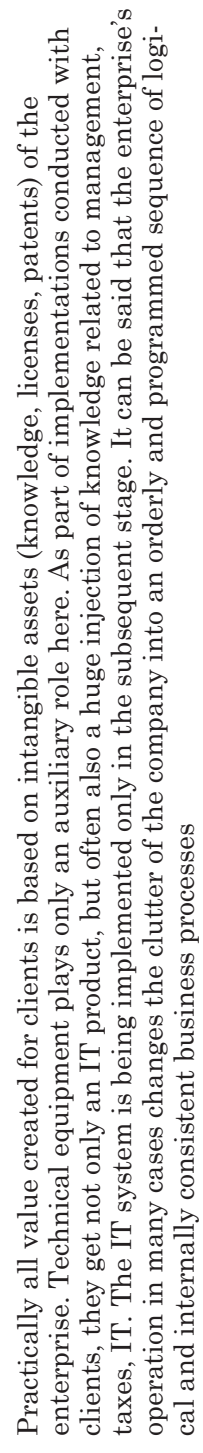 \\
\hline 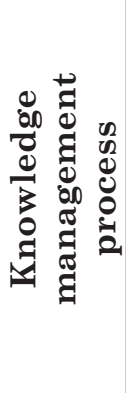 & 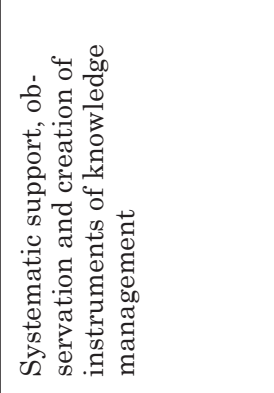 & 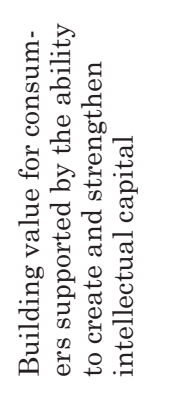 & 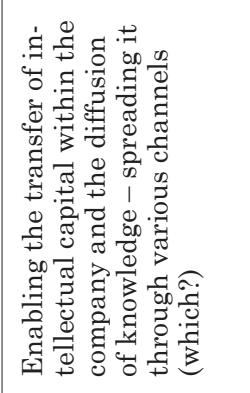 & 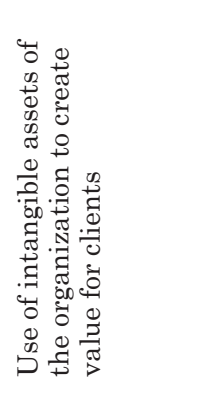 \\
\hline
\end{tabular}




\begin{tabular}{|c|c|c|c|}
\hline 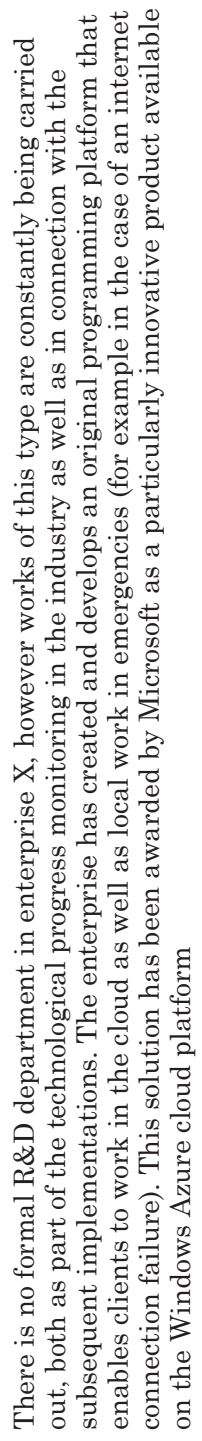 & 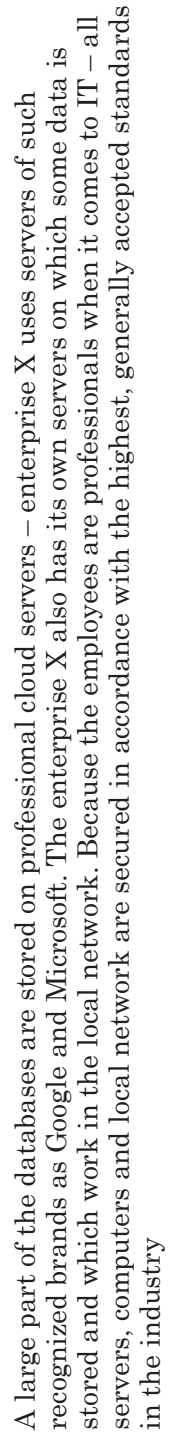 & 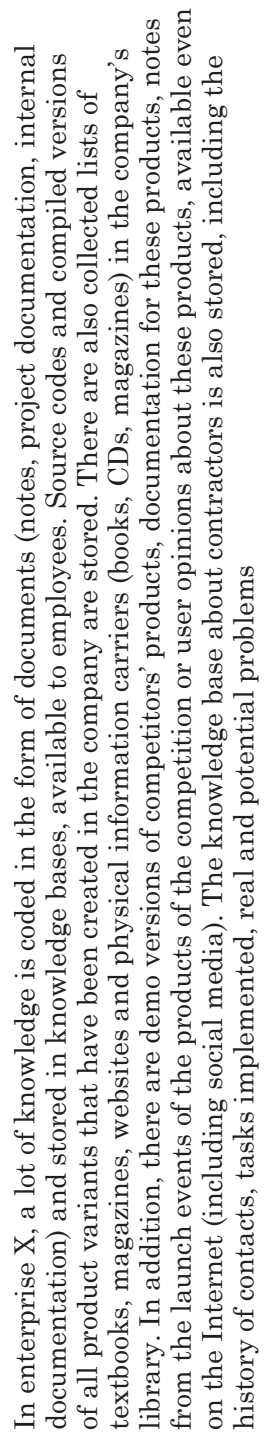 & 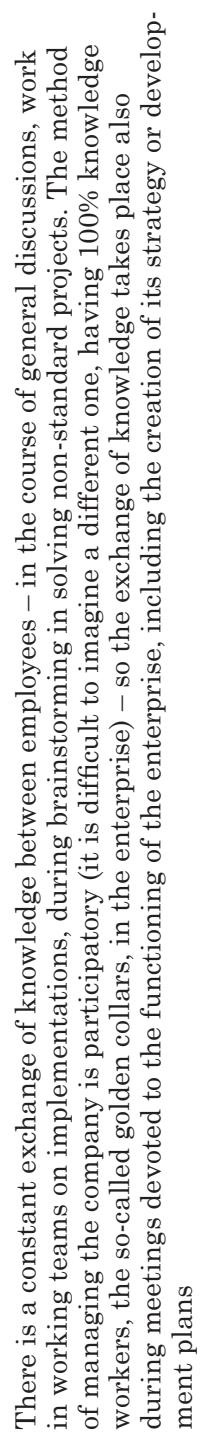 \\
\hline 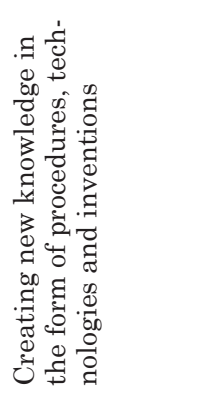 & 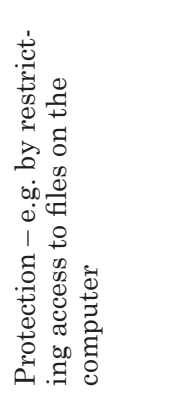 & 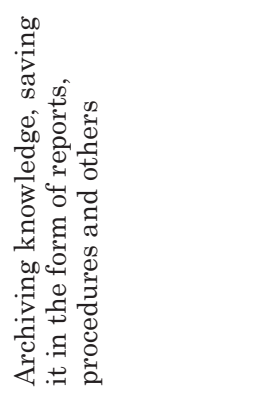 & 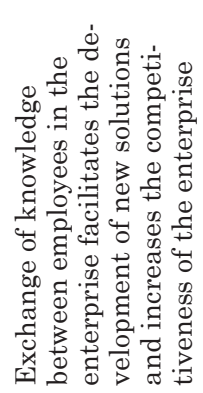 \\
\hline
\end{tabular}




\section{CONCLUSIONS}

The assessment of logistics knowledge management in the studied micro-enterprises showed that there is a large dependence between human capital and the implementation of logistic processes in which knowledge is an indispensable element. Owners of micro-enterprises had practical knowledge necessary to establish and run a business. When assessing the owner's individual intellectual capital and managing human capital, the following categories can be distinguished:

- comprehensive and specialist knowledge of the company's operations, knowledge of logistics processes, market, customer expectations,

- experience in running business in the field of legal regulations, knowledge about competitors, and intuitive assessment of development forecasts,

- personality traits, abilities and skills, such as pursuing a goal, perseverance, ability to manage employees,

- $\quad$ entrepreneur education - in the majority of surveyed companies it was a university degree,

- ability to manage intellectual capital in the enterprise - in most companies this position was rated highly, especially in the field of information flow within the company.

The level of employees' knowledge potential influenced the implementation of logistic processes, especially in those surveyed enterprises where intellectual capital was highly valued. Among the factors shaping the role of human capital in the process of logistics knowledge management the most important are: improving employees' skills and competences, creating a good working atmosphere (especially in family businesses), they included the following elements:

- $\quad$ awareness of the role of knowledge in a micro-enterprise,

- receptivity to new knowledge,

- active search for knowledge coming from various sources,

- learning ability,

- improving skills and competences,

- ability to cooperate with other enterprises,

- readiness to share knowledge,

- openness to new requirements and increase of customer expectations, 
- $\quad$ ability to use modern techniques and technologies, including IT.

On the basis of research, the following elements of logistic knowledge management in which human capital is important are distinguished in the group of micro-enterprises:

- using the knowledge of the owner,

- creating an atmosphere conducive to knowledge acquisition by employees,

- acceptance of employee learning processes,

- archivization of hidden knowledge,

- acquiring hidden knowledge from the environment,

- creating conditions for team work and cooperation,

- organizing courses and training,

- interactive cooperation with clients and other companies in the area of building knowledge resources,

- including suppliers in the knowledge management process.

As a result of the research, it can be noticed that the role of human capital in managing logistic knowledge is huge and the statements of the surveyed managers indicate the necessity of continuous learning and using various sources of knowledge. Therefore, the question arises - what offer should be made by universities for employees of micro-enterprises who are looking for knowledge. It seems that this problem will become an important trend in education, especially in the context of the digitization of the economy.

It is therefore advisable to continue research on the role of human capital in modern micro-enterprises that are aiming at entering the economy 4.0.

\section{REFERENCES}

Bławat, F. (2003). Przedsiębiorca w teorii przedsiębiorczości i praktyce małych firm. Gdańsk: Wyd. Gdańskiego Towarzystwa Naukowego.

Bodrow, W. (2006). Knowledge Management in Small and Medium-sized Enterprises. [proceedings of PROLAMAT 2006, IFIP TC5 International Conference, $15^{\text {th }}-17^{\text {th }}$ June 2006, Shanghai], http://link.springer.com/book/10.1007/0387-34403-9 (accessed: 7th Sep 2018).

Czechowska-Świtaj, T. (2005). Zarzadzanie kapitałem intelektualnym w organizacji. Warszawa: Wyższa Szkoła Menedżerska. 
Edvinsson, L. \& Malone, M. (2001). Kapitat intelektualny. Warszawa: PWN.

Gierszewska, G. (2011). Zarzqdzanie wiedzq w przedsiębiorstwie. Warszawa: Oficyna Wydawnicza Politechniki Warszawskiej.

Grudzewski, W. \& Hejduk, I. (2006). Systemy zarządzania wiedzą warunkiem wzrostu wartości firmy. In: B. Dobiegała- Korona, A. Herman (red.). Wspótczesne źródta wartości przedsiębiorstwa (pp. 243-260). Warszawa: Difin.

Hill, J., Nancarrow, C. \& Wright, L.T. (2002). Lifecycles and crisis point in SMEs: A case approach. Marketing Intelligence and Planning, 20(6), 361-369.

Janczewska, D. (2011) Marketingowo-logistyczne elementy zarządzania firmą rodzinna. In: Ł. Sułkowski (red.). Firmy rodzinne-determinanty funkcjonowania i rozwoju (pp. 179-192). Łódź: Wyd. Społecznej Akademii Nauk w Łodzi.

Janczewska, D. (2014a). Zarządzanie kapitałem intelektualnym jako zasobem mikro przedsiębiorstwa. In: M. Piekut (red.). Nauka gospodarce-gospodarka nauce (pp. 193-204). Warszawa: Oficyna Wydawnicza Politechniki Warszawskiej.

Janczewska, D. (2014b). Implementacja metodyki myślenia sieciowego w marketingowo-logistycznym zarządzaniu przedsiębiorstwem. In: J. Dworak, M. Boguszewicz-Kreft, E. Magier-Łakomy (red.). Determinanty konkurencyjności przedsiębiorstw (pp. 13-25). Gdańsk: Wyd. Wyższej Szkoły Bankowej.

Janczewska, D. (2016a). Proces zarządzania wiedzą w mikroprzedsiębiorstwie w aspekcie przekształcania w firmę inteligentną. Przedsiębiorczość - Edukacja, $12,164-175$.

Janczewska, D. (2016b). Uwarunkowania procesu przekształcania mikroprzedsiębiorstwa w organizację inteligentną. In: H. Kościelniak, K. Brendzel-Skowera (red.). Wyzwania i perspektywy przedsiębiorczej organizacji. Innowacje. Konkurencja. Przedsiębiorczość (pp. 119-131). Częstochowa: Wyd. Politechniki Częstochowskiej.

Janczewska, D. (2017a). Badanie procesu zarządzania marketingowo-logistycznego w mikroprzedsiębiorstwie. Zarzadzanie Innowacyjne w Gospodarce i Biznesie, 2(25), 193-204.

Janczewska, D. (2017b). Business model concept based on knowledge in microenterprise. Przedsiębiorczość - Edukacja, 13, 196-204.

Janczewska, D. (2017c). Creating success strategy as an elements of business models in microenterprises. Przedsiębiorczość i Zarzadzanie, 18(1), 73-84.

Juchniewicz, M. \& Grzybowska, B. (2010). Innowacyjność mikroprzedsiębiorstw $w$ Polsce. Warszawa: PARP.

Kamińska, B. (2016). Rozwój kapitału ludzkiego jako czynnik rozwoju firmy. Zeszyty Naukowe Wyższej Szkoły Humanitas, Zarzqdzanie, 3, 159-172.

Karaszewski, R. \& Klemke-Pitek, M. (2012). Problematyka zarządzania wiedzą w świetle doświadczeń zagranicznych oraz koncepcja wdrażania innowacyjnych 
rozwiązań w polskiej gospodarce. Finanse, Rynki Finansowe, Ubezpieczenia, $55,55-78$.

Kozioł, M. (2013). Wykorzystanie e-learningu w procesie kształcenia pracowników małych i średnich przedsiębiorstw. Zeszyty Naukowe Małopolskiej Szkoty Ekonomicznej w Tarnowie, 22(1), 45-57.

Listwan, T. (2006). Zarzqdzanie kadrami. Warszawa: C.H. Beck.

Łobejko, S. (2009). Trendy rozwojowe inteligentnych organizacji w globalnej gospodarce [ekspertyza]. Warszawa: PARP.

Malara, Z. (2009). Umiejętność zarządzania wiedzą i kapitałem intelektualnym jako czynnik sukcesu współczesnego przedsiębiorstwa. Prace i Materiały Wydziału Zarzqdzania Uniwersytetu Gdańskiego, 2-3, 809-821.

Morrison, A. \& Bergin-Seers, S. (2002). Pro-growth small businesses: learning architecture. Journal of Management Development, 21(5), 388-400.

Nogalski, B., Karpacz, J. \& Wójcik-Karpacz, A. (2004). Funkcjonowanie i rozwój matych i średnich przedsiębiorstw. Bydgoszcz: Oficyna Wydawnicza Ośrodka Postępu Organizacji Sp. z o.o.

Nonaka, I., Takeuchi, H. (1995). The Knowledge Creating Company: How Japanese Companies Create The Dynamics Of Innovation. Oxford-New York: Oxford University Press, Inc.

Penc, J. (1997). Leksykon biznesu. Warszawa: Agencja Wydawnicza Placet.

Probst, G.J.B., Raub, S., Romhard, S. (1999). Managing Knowledge: Building Blocks for Success. London: Wiley.

Sajkiewicz, A. (1999). Człowiek - kreator wartości przedsiębiorstwa. In: A. Herman, A. Szablewski (red.). Zarzadzanie wartościa firmy (pp. 61-93). Warszawa: Poltext.

Schuler, R.S. (1992). Strategic human resources management: Linking the people with the strategic needs of the business. Organizational Dynamics, 21(1), 18-32.

Senge, P. (2012). Piata dyscyplina Teoria i praktyka organizacji uczacych sie. Warszawa: Wolters Kluwer.

Sokołowska, A. (2005). Zarzadzanie kapitałem intelektualnym $w$ matym przedsiębiorstwie. Warszawa: Polskie Towarzystwo Ekonomiczne.

Sopińska, A. \& Wachowiak, P. (2006). Modele zarządzania wiedzą w przedsiębiorstwie. E-Mentor, 1(14), http://www.e-mentor.edu.pl/artykul/index/numer/14/id/275 (accessed: 1st March 2016).

Sułkowska, J. \& Sułkowski, Ł. (2011). Modele zarządzania zasobami ludzkimi w organizacjach medycznych. Prace Naukowe Uniwersytetu Ekonomicznego we Wroctawiu, 226, 53-62.

Sveiby, K.-E. (1997). The New Organizational Wealth: Managing and Measuring Knowledge Based Assets. San Francisco: Berret Koehler. 
Sveiby, K.E. (1998). Intellectual capital: Thinking ahead. The Australian Accountant, $68(5), 18-23$.

Sydanmaanlakka, P. (2002). An Intelligent Organization: Integrating Performance, Competence and Knowledge Management. Oxford: Capstone Publishing Limited.

Szopik-Depczyńska, K. \& Korzeniewicz, K. (2011). Kapitał ludzki w modelu wartości. Zeszyty Naukowe Uniwersytetu Szczecińskiego. Studia i Prace Wydziału Nauk Ekonomicznych i Zarzadzania, 24, 177-204.

Teece, D.J. (2000). Managing Intellectual Capital: Organizational, Strategic and Policy Dimensions. Oxford-New York: Oxford University Press.

Von Krogh, G., Nonaka, I. \& Aben, M. (2001). Making the most of your company's knowledge: A strategic framework. Long Range Planning, 34(4), 421-439.

Żołnierski, A. (2005). Innowacyjność polskich mikroprzedsiebiorstw. Warszawa: PARP. 